\title{
Discussion and Analysis of Life-based Education of Core Socialist Values among College and University Students
}

\author{
Zhang Yajun \\ School of Humanities, Economics and Law \\ Northwestern Polytechnical University \\ Xi'an, PR China \\ 76406832@qq.com
}

\begin{abstract}
This paper aims to enhance education effects of core socialist values among college and university students. In actual education, work has been done to set goals and principles for life-based education of core socialist values among college and university students build the student-centered and life-based education model and implement the life-based education reform. This education reform activity has deepened the Chinese college and university students' understanding of the Chinese core socialist values, so that the vast majority of college and university students have more confidence in core socialist values and apply it.
\end{abstract}

Keywords-college and university students; core socialist values; life-based education; education model

\section{INTRODUCTION}

Judging from relevant literature on "core socialist value education of college and university students" included in the CNKI, first research on "life-based education of core socialist values among college and university students" could be traced back to the early 21 st century. Research has experience over 10 years of development in this field. This development process can be divided into three stages. The first stage is the budding stage (2003-2006), started with and marked by the publishing of relevant literature on "life-based ideological and political education", which had gradually inspired scholars to focus on "life-based" issues in the field of ideological and political education. The second stage is the preliminary discussion stage (2006-2012), started with and marked by the formal presentation of "core socialist value system" in the Sixth Plenary Session of the Sixteenth Central Committee. Many scholars concentrated their efforts on investigating "core socialist value education of college and university students" and pursued "the life-based method" as one education path. Meanwhile, scholars began to condense core socialist values in the "core socialist value system" from different perspectives, and applied "condensing" fruits into research on "core socialist value education of college and university students". The third stage is the formal exploration (2012-present), started with and marked by the formal generalization of core socialist values with 24 characters in the report at the 18th Party Congress. A large group of scholars have begun to focus on "core socialist value education of college and university students", Moreover, along with the deepening of theoretical explorations, research on "life-based education of core socialist values" has been involved. Therefore, to some extent, the release of the report at the 18th Party Congress can be seen as the "starting point" of this research.

In the academic circle, some achievements have been gained in the research field of "life-based education of core socialist values among college and university students". In particular, rich explorations have been made of basic theories in this field, such as theoretical origins, connotations, features and significance of life-based ideological and political education, to lay a sound foundation for further research. However, on the whole, research in this field is still in its infancy and has many weaknesses, which leaves a large space for the further research in this paper.

\section{Connotation of Life-BASEd Education of CoRE SOCIALIST VALUES AMONG UNIVERSITY AND COLLEGE STUDENTS}

The so-called life-based education of values refers to education which is centered by the modern social life to make full development and use of modern life resources which have vale-guiding functions, promote people to develop their own values and independently build their value system through practices in value life, and take life as the starting point and ending point of education. This education model requires educators to start with the real life, reality and real activities of the educated people and take emotional and practical ways, so that the educated can experience and perceive in real life, thereby gradually building their own values. In life-based education of core socialist values among college and university students, life practices which can guide mainstream values can be seen in each education link, so as to set college and university students free from the plain and abstract theoretical system of core socialist values, and create opportunities and scenes for college and university students to feel nature and society, so that they can launch communications and dialogues with the real world in the daily life and gradually identify and resonate with core socialist values, thereby developing a positive attitude to learn, publicize and implement core socialist values. Life-based education of core socialist values among college and university students is actually a process 
about mutual respect, honesty and fraternity and active and equal dialogues, a process which achieves a dynamic integration of the real life with the value theory system, a process during which students feel and perceive life through practice, and a process to guide college and university students to build lofty ideals and create a better life. In addition, "life" in "life-based education" refers to the life which has a broad sense and universal meaning and reflects the nature and law of the social development and the refined life "which is produced after eliminating the false and retaining the true, proceeding from the one to the other and from the exterior to the interior", instead of life in a general sense.

\section{INEVITABILITY TO INTEGRATE LIFE-BASED EDUCATION WITH CORE SOCIALIST VALUE EDUCATION OF COLLEGE AND UNIVERSITY STUDENTS}

To thoroughly implement the spirit of the report at the 18th Party Congress and the Third Plenary Session of the 18th Central Committee and actively cultivate and practically implement core socialist values, the CPC News Website released the "Opinions on the Cultivation and Application of Core Socialist Values" on December 23, 2013. "Opinions" has 6 parts and 23 articles including the great significance and guiding ideology to cultivate and apply core socialist values, integrating the cultivation and practice of core socialist values into the entire process of national education, cultivating and applying core socialist values in the specific economic development and social governance, strengthening propaganda and education of core socialist values, launching practical activities cultivating core socialist values, and enhancing the organization and leadership of cultivating and applying core socialist values. According to the spirit and requirements of "Opinions", pursuing the specific and life-based education of the core socialist value among college and university students has become an inevitable trend.

Firstly, core socialist values are derived from a systematic summary of the socialism building with Chinese characteristics. In China, core socialist values were gradually generated, proposed and identified in a variety of real life of the country, society and individuals. The 18th National Congress of the CPC promotes prosperity, democracy, civility, and harmony, upholding freedom, equality, justice and the rule of law, and advocates patriotism, dedication, integrity, and friendship, to cultivate and apply core socialist values. In terms of contents and formation, the core socialist values use 24 Chinese characters to reflect value objectives of the country, value orientation of society, and value criteria of individuals. In terms of resource and theory, the 24-character generalization of the core socialist values not only accords with requirements of socialism development with Chinese characteristics and inherits excellent achievements of the Chinese traditional culture and human civilization, but also is an important conclusion drawn based on the consensus on social values in China. However, from a practical point of view, core socialist values would be nothing but a theory with no vitality, like water with no source and a tree with no root, if they are interpreted inseparably from the political, economic and cultural life at a specific history stage of China, specific social life or daily life or individuals.
Secondly, the cultivation and application of core socialist values must be linked up to the actual life of the subject of cultivation and application. According to the Marxist Philosophy, life is a quite inclusive concept, covering almost activities of all people. In classical writings of Marxist, production of material goods, material life, country life, social life, personal life, daily life, political life, practical life and other terms were frequently used. All of these life types can be seen as an integral part of people's lives, reflecting the generation of people's lives and people's state of existence from different perspectives. The 24-character core socialist values at the 18th National Congress of the CPC are a high generalization of connotations of core socialist values, which strive to make people in all walks of life to accept and apply it, instead of purely conducting theoretical deduction and education. To achieve real learning, understanding, believe and application of core socialist values, it is quite essential to incorporate core socialist value education into actual work and life of different people. Only when people perceive and realize the significance and charm of core socialist values in real life, would they possibly resonate and identify with core socialist values. Once apart from practices of the masses, a theory would be destined to be lifeless, no matter how profound it is. Therefore, only theories which come from practices of the masses and pass the test of practical activities of the masses can become powerful theoretical weapons which can be used to arm people.

Lastly, existing life-based education research findings can also contribute to the effective implementation of core socialist value education. In the education circle, many scholars and educators have been working hard to make practices and explorations Life-based education has been gradually perfected popularized and applied in education practice. In recent years, many ideological and political educational workers have applied life-based education in their work, in hope of transforming the traditional ideological and political education, and changing the current situation of the traditional ideological and political education. These findings also contribute to the application of life-based education of core socialist values. Life-based education and the "three close" requirements (close to the reality, life and students) for ideological and political education share the same goal to improve the effectiveness of education. Therefore, applying the life-based education of core socialist values among college and university students is bound to effectively promote the life-based education of core socialist values to move "close to reality, life and students".

\section{MOdel BuILding OF LIFE-B ASEd EdUCATION OF CORE SOCIALIST VALUES AMONG COLLEGE AND UNIVERSITY STUDENTS}

\section{A. Basic Principle and Fundamental Purpose}

On the one hand, the basic principle of "being based on life, oriented by life and for life" must be pursued in building the life-based education model of core socialist values among college and university students. "Based on life" requires to be established in the real life of students in core socialist value education. "Oriented by life" stresses that core socialist value education and teacher-student relationships must rely on real 
life, reflecting requirements for social life of people. "For life" is a requirement for the function and objective of life-based education. It is a starting point and ending point of core socialist value education.

On the other hand, in building the life-based education model of core socialist values among college and university students, efforts should be placed to promote students to "walk into life, out of wrong region, into the soul and towards the future" as the fundamental purpose. To achieve this purpose, teachers should launch democratic dialogues with and open their hearts to students. Moreover, teachers should also educate life-based education theories are integrated and taken as the theoretical basis, and the teaching material system is transformed into the teaching system. Moreover, teaching contents are re-transformed into life-based topics in teaching. On this basis, teachers should further apply the modern education technology, integrate with the life experience and rich social life of students, follow the principle of "based on life, oriented by life and for life", and eventually realize the goal of cultivating core socialist values among college and university students, so that core value education can truly "walk into life, out of wrong region, into the soul and towards the future".

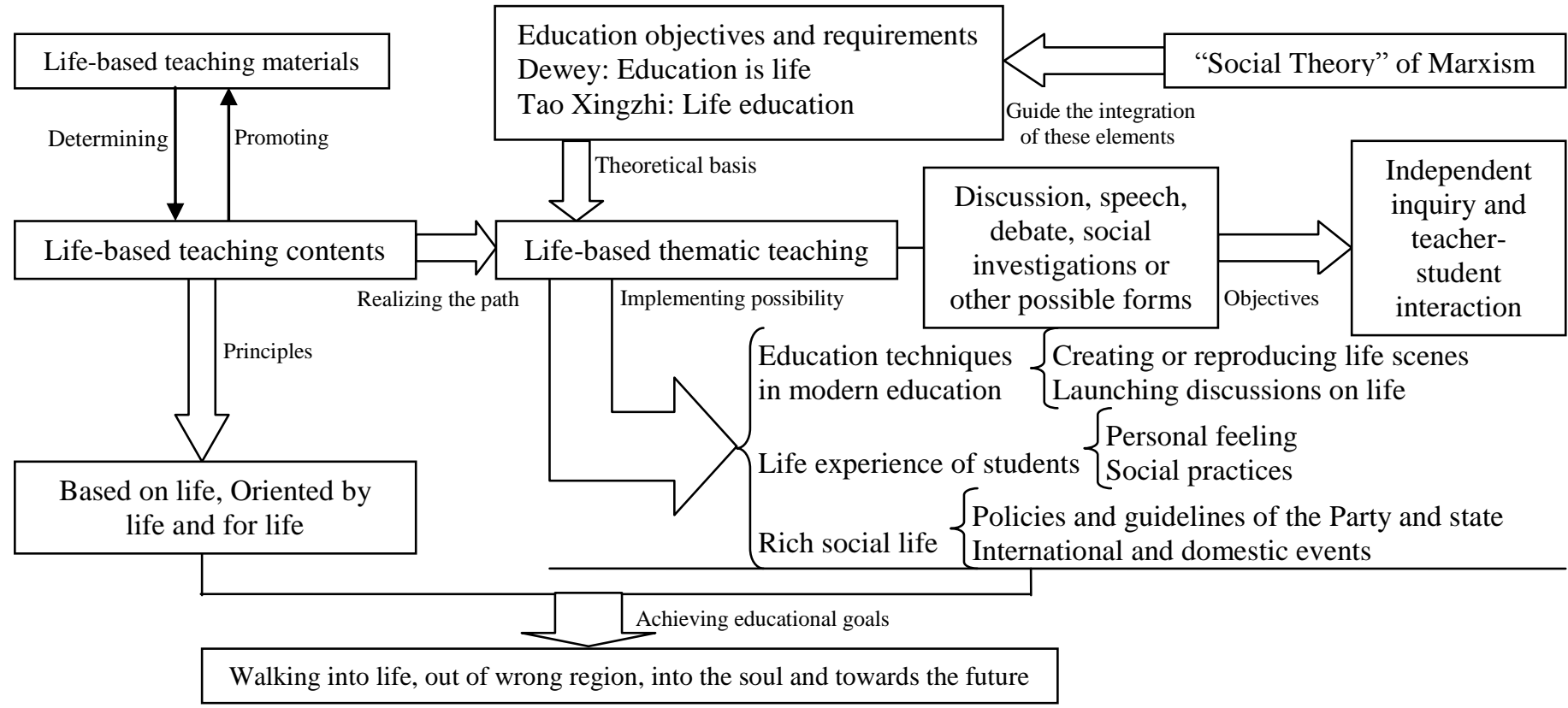

Fig. 1.Overall design of life-based education of core socialist values among college and university students

college and university students about core socialist values, on the basis of integrating into the real life. Only in this way, can core socialist value education truly become the soul, navigation and enlightenment science for college and university students, thereby developing into a guidance beacon of college and university students in their future life.

\section{B. Basic Model Design}

If it is seen as a phenomenon, life-based education of core socialist values among college and university students is an integration of higher education with social communication and fusion. In terms of its essence, life-based education of core socialist values refers to the education practice which connects college and university students to society and expands the life value of college and university students through social progress In this paper, guided by "Opinions on the Cultivation and Application of Core Socialist Values", the author attempts to build a life-based education model of core socialist values among college and university students, on the basis of discussing the purpose, contents and methods of life-based education and core socialist value education.

The overall design of this model (see Fig. 1.) is built under the guidance of the "life-based theory" of Marxism. Relevant

\section{Flow Path of Implementing Life-based Education}

The implementation of the teaching model should be realized through specific teaching processes (see Fig. 2.). However, in order to truly implement life-based education of core socialist values, teachers should implement core socialist value education through a specific education and teaching process. Therefore, the teaching flow path of life-based education of core socialist education among college and university education is designed in this research. In this flow path, teachers serve as "directors" and guiders, while students are the center of teaching activities to make teaching-student interaction to launch a series of teaching activities, in order to achieve fixed goals. In this process, firstly, teachers should implement teaching activities to simulate emotions, and create life scenes to arouse learning interests of students and mobilize students' initiative to learn. Secondly, teachers should create tasks; broaden students' horizons based on life, and guide students to actively explore practical problems and complete goals set by teachers, so that students can learn happily in the process of identifying, studying and solving problems. Thirdly, teachers should interact with students, and listen to and launch dialogues with students to jointly discuss a series of problems concerning core socialist values, so that students can conduct 


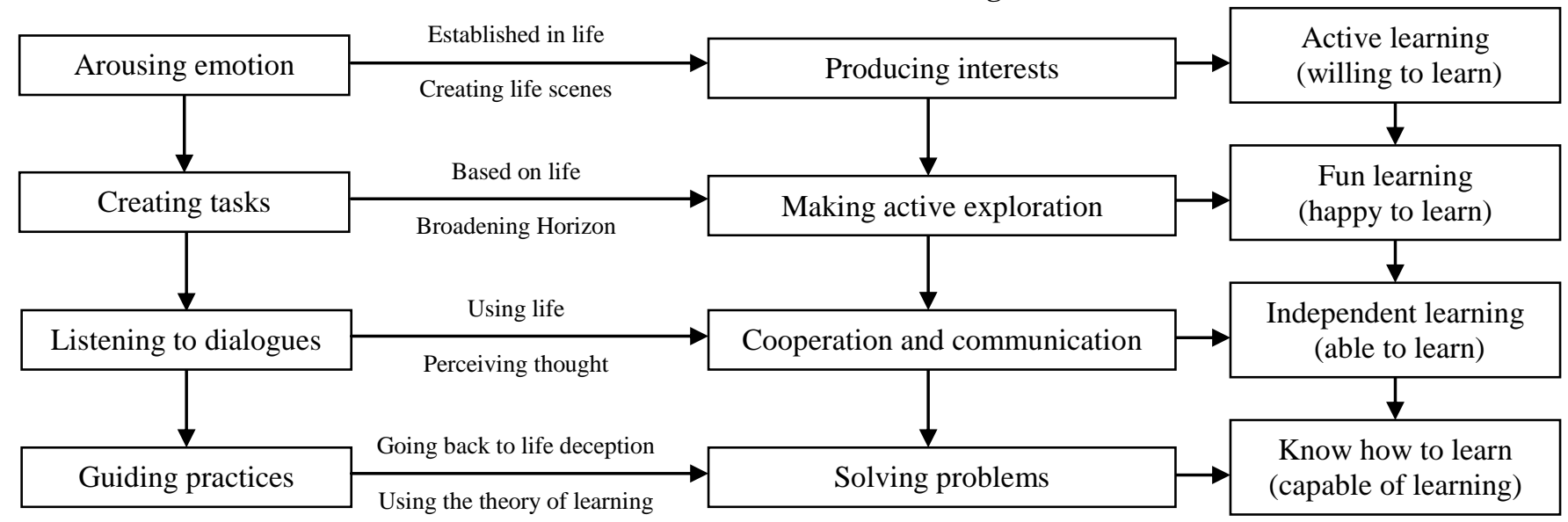

Fig. 2. Flow Chart of Life-based Education of Core Socialist Values among College and University Students

independent learning and realize the objective existence of core socialist values. Lastly, teachers should guide students to apply core socialist values into the real life and identify and solve practical problems, in order to achieve the ultimate goal of making students know how to learn and learn well.

\section{CONCLUSION}

The implementation of life-based education strategy can enhance the effect of core socialist values education among college and university students. First, life education can indoctrinate college and university students with socialist core values. Secondly, the education rooted in the students' life can promote college and university students to turn the core socialist values into behavioral habits. Lastly, the good social behavior of college students can also affect people around them and promote the spread of socialist core values. Only when college and university students take the initiative to cultivate and apply the core socialist values, can college and university students eventually become the socialist builders and successors of having both ability and political integrity.

\section{REFERENCES}

[1] Shang Lijuan. Ideological and Political Education: to be Life-based [J]. Ideological and Political Work Study, 2005 (10): 24. (In Chinese)

[2] Zhao Xiqun. Seeking the Source of Life-based Education [J]. Academic Journal of Zhengzhou University, 2008 (2): 25-27. (In Chinese)

[3] Li Peiyuan. Exploration of Life-based Education of Core Socialist Values in Colleges and Universities [J]. Henan University of Technology (Social Sciences), 2012 (4): 150. (In Chinese)

[4] Li Chunmei \& Liu Huiting. Construction and Cultivation of College Students' Core Socialist Values [J]. Learning Monthly, 2011 (7): 88-89. (In Chinese)

[5] Kan Heqing. Effective Channels for Educating College and University Students about Core Socialist Values [J]. Ideological and Political Work Study, 2011 (3): 23. (In Chinese)

[6] Xu Wensheng. Basic Connotations of Life-based Ideological and Political Education [J].New Course Learning (Middle month), 2011 (3): 11-12. (In Chinese)

[7] Zheng Jinpeng. Research on Life-based Approach for Core Socialist Value Education [J]. China Adult Education, 2015 (9): 21-23. (In Chinese)

[8] Liu Jiping \& Shi HaiBing. On Elements and Structure of Life-based Education Model of Core Socialist Values for College and University Students [J]. Modern Education Science, 2015 (1): 22-25,31. (In Chinese)

[9] Liu Liquan. Research Review of Ideological and Political Education in Colleges and Universities [J]. Ideological and Political Education, 2010 (1) 23-26,31. (In Chinese) 